Article

\title{
Analysis of Determinants Affecting Organic Production: State Evidence from the United States
}

\author{
Yongrui Hou ${ }^{1}$, Tianyuan Luo ${ }^{2, *}$ and Jing Hao ${ }^{1}$ \\ 1 School of Public Affairs, Chongqing University, Chongqing 400044, China; 201901132073@cqu.edu.cn (Y.H.); \\ 202101021002@cqu.edu.cn (J.H.) \\ 2 School of Economics and Finance, Xi'an Jiaotong University, Xi'an 710049, China \\ * Correspondence: luoterry@xjtu.edu.cn
}

Citation: Hou, Y.; Luo, T.; Hao, J. Analysis of Determinants Affecting Organic Production: State Evidence from the United States. Sustainability 2022, 14, 503. https://doi.org/ $10.3390 /$ su14010503

Academic Editor: Michael S. Carolan

Received: 4 December 2021

Accepted: 29 December 2021

Published: 4 January 2022

Publisher's Note: MDPI stays neutral with regard to jurisdictional claims in published maps and institutional affiliations.

Copyright: (c) 2022 by the authors. Licensee MDPI, Basel, Switzerland. This article is an open access article distributed under the terms and conditions of the Creative Commons Attribution (CC BY) license (https:// creativecommons.org/licenses/by/ $4.0 /)$.

\begin{abstract}
As the demand for organic products quickly grows in the U.S., the domestic supply of organic commodities has stagnated and failed to meet the increasing needs. To expand the organic supply capacity in the country, it is crucial to identify the key factors that could effectively promote the scale of organic farming in the U.S. Using a multivariate analytic model and state level data from multiple sources and years, this study examines a wide range of determinants that could affect organic agriculture. The results show that research funding would significantly increase organic vegetable production and the number of organic farms. The development of organic farming could be greatly encouraged by the support of research institutions. In addition, the evidence shows that abundant farm workers are essential for the organic farming sector, which is labor-intensive. Finally, a large population base could create a more stable consumer group that would promote the development of organic agriculture. These results suggest the importance of exploring and expanding consumer groups for organic commodities. These findings provide insightful implications that research support, labor availability, and a solid consumer base are crucial to boost the organic sector in the U.S. and other countries.
\end{abstract}

Keywords: organic farming; determinants; research funding; labor availability; state level analysis

\section{Introduction}

Organic farming has been considered a possible model that could further advance the development of modern agriculture which faces with many obstacles nowadays (USDA 1980). Previous literature has discussed the importance and impacts of organic farming for human society, local economy, agricultural sustainable development, and people's daily lives. Firstly, organic farming could produce enough food on a global per capita basis without increasing the burden on and pollution problems associated with local agriculture [1,2]. Secondly, organic hotspots have a positive and significant impact on local economic indicators. The quantity and quality of human capital will affect local wealth, and the existence and effective utilization of resources may affect local development [3-5]. Thirdly, conversion to organic farming is not only an agroeconomic practice, but also a multidimensional subject, involving farmers' motivations, technical problems, natural conditions, and government policies [6-9]. Fourthly, the development of organic farming is influenced by multiple factors such as social, structural, and intellectual factors [10]. Therefore, the complexity of organic farming could notably affect the society and economy in return.

Showing the importance of organic farming to the society and economic development, the total sales of organic products in the US have grown from only 7.9 billion dollars in 2000 to notably 52.5 billion dollars in 2018 , which can be translated to an approximately $560 \%$ increase in organic commodity sales over the years [11]. The rapidly expanding demand for organic products has led the government to pay more and more attention to the organic market and to introduce a series of policies that could promote organic farming 
in the U.S. and increase the supply of organic products. The 2018 Farm Bill offered a total of USD395 million funding for the Organic Research and Extension Initiative that aims to substantially help to build a more efficient organic production system in the country [11]. Moreover, the 2018 Farm Bill will build a better organic market by enhancing oversight and enforcement of the organic supply chain that could shorten the distance and time that organic products need to reach U.S. families [12]. Growth of the organic farming sector could bring many benefits such as promoting agricultural sustainability, reducing environmental pollution, increasing farmers' income, stimulating the rural economy, diversifying market commodities, and providing a greater variety of healthy food for consumers. Given the growing role of organic products in people's daily lives, it is important to understand what are the factors and key determinants that could affect the development of organic farming and production. This paper mainly studies the impact of USDA and state approved grants, total farm labor, and total population. USDA and state approved grants provide technical and financial help for organic production. Total farm labor represents human conditions. Because organic agriculture is different from general agriculture, it needs more labor to promote production. Total population explains the impact on organic production from the demand side. Based on these findings, the governments and relevant stakeholders could, therefore, develop suitable and effective policies for the organic farming sector.

First, even though the demand for organic products in the U.S. has increased over time, the supply of organic commodities has stagnated in recent years [13]. The lag in supply is largely due to the slow growth of the organic agricultural industry and makes identifying the key factors an urgent task. Many people have explored the reasons for the mismatch between the supply of organic products and the demand. Klonsky and Tourte discussed the current status and direction of organic production in the United States and found that data on the number of organic growers and amount of commodities grown are available only for certified growers, which may underestimate the total amount of organic production [14]. Due to the aging of the American population and the improvement of living standards, people's demand for food quality would grow and therefore increase the market demand for organic products [15]. The 2002 USDA National Organic Standards regulation in most cases requires farmland to be dedicated to organic farming for 3 years before a farm's products can be labeled as organic [16]. This creates a lag between increases in demand and supply from farms.

Second, there is an uneven distribution of organic farming across the states in the U.S. [17]. Organic agriculture is concentrated primarily in metropolitan areas in the Northeast and the Pacific Coast, and in rural areas having desirable natural amenities such as the Northern Great Lakes and the Mountain West [18]. The unequal development of organic agriculture in the country deprives farmers in the southeastern region of a great opportunity to diversify and enhance their farm incomes. A clear vision of the key determinants could help policymakers to narrow the regional gaps in organic farming and effectively encourage organic agriculture in lagging states. Third, an investigation of the key determinants at the state level would complement previous studies that focused on organic production at the farm level [19-21] or county level [22]. Previous literature suggested that the use of direct marketing, the number of crops, the use of computers in production, the age of the farmer, greater size of farm, greater productivity of labor, farmers' motivation and perceptions about organic farming, and policies are significant determinants of the choice to adopt organic methods of production.

This study distinguishes itself from previous studies and contributes to the body of literature in several significant ways. First, this study is one of the few studies that comprehensively examines the impact of macro-level factors on organic production in the U.S. Specifically, this research looks at the determinants including macroeconomic factors, policy factors, demographic factors, and agricultural input factors that cover many aspects of organic farming. Macroeconomic factors are different from micro level factors (such as farm level factors). From the perspective of economics, macro factors are related to national macrocontrol policies, which generally refer to the influence of government policies. Micro factors 
relate mainly to entrepreneurs and consumers. Problems in daily life can also be classified as micro factors. Second, this study contributes to relevant studies by looking at all states and multiple years from 2000-2016 in the U.S. The comprehensive sample could make the results more nationally representative, and they could more accurately reflect the trends of organic farming in the U.S. during recent years. Generally speaking, the literature concerning the development of organic agriculture in some areas lacks universality, because it may only be useful for the characteristics of a certain area. Experiences in other organic settings such as in western Uganda indicate that grassroots-organized lobbying and policy advocacy processes have been effective in changing the perception of local government technical staff and policy makers [23]. Schafer, Nolting and Engel analyze the possible effects of organic agriculture on sustainable regional development in peripheral Eastern German regions [24]. In order to promote the development of organic agriculture, farmers should explore a broader market through marketing cooperatives, such as the research and extension center of Oregon State University in southern Oregon [25]. Third, we would like to note that this study specifically looks at different crops such as vegetables and fruits, which is rarely found in previous studies. Due to the disparities in their labor-intensive nature and agronomic practices, some crops may be affected differently by particular factors compared to other crops. This study pays attention to such disparities and tries to find out the determinants for specific crops. Some literature only considers crops in general, but cannot give specific guidance relating to specific crops such as vegetables and fruits $[20,26,27]$.

The remainder of the article is organized as follows: Section 2 introduces the background of organic production in the U.S. Section 3 discusses the data and the multivariate model used for identifying the key determinants. Section 4 presents the empirical results and discussion. Section 5 concludes.

\section{Background and Conceptual Framework}

\subsection{Organic Commodity Demand and Supply in the U.S.}

The effective organic regulatory program and labeling requirements of USDA have triggered a fast rise in consumer demand for organic food during the past years [28-30]. The rapid expansion has highlighted the challenges that are faced by the organic sector today: a continuously increasing consumer demand for organic products and a shortage of new organic producers to meet the demand, which constrains and limits the growth of the whole organic sector.

Plot A in Figure 1 shows the trend since 2000 in total acreage of organic production as well as the total number of organic farms in the U.S. As can be seen, the level of organic production including the number of organic farms and organic production acreage has been increasing over the years, particularly after the year 2006. The notable increase in U.S. organic production indicates that organic agriculture is playing a more and more important role in the farm sector and in improving the economic situation and profitability of many farms in the U.S. However, plot A also shows that after 2010, the growth of total organic production in the U.S. has halted and entered a plateau where the total number of organic farms has remained at about 13,000 . The total acres of organic agriculture have fluctuated significantly across the years, with an average of about 4 million acres per year. The latest statistics of organic production in 2016 indicate that organic production land totalled of 5.02 million acres, which is even lower than that in 2011 which had a total of 5.38 million acres of organic farming. 

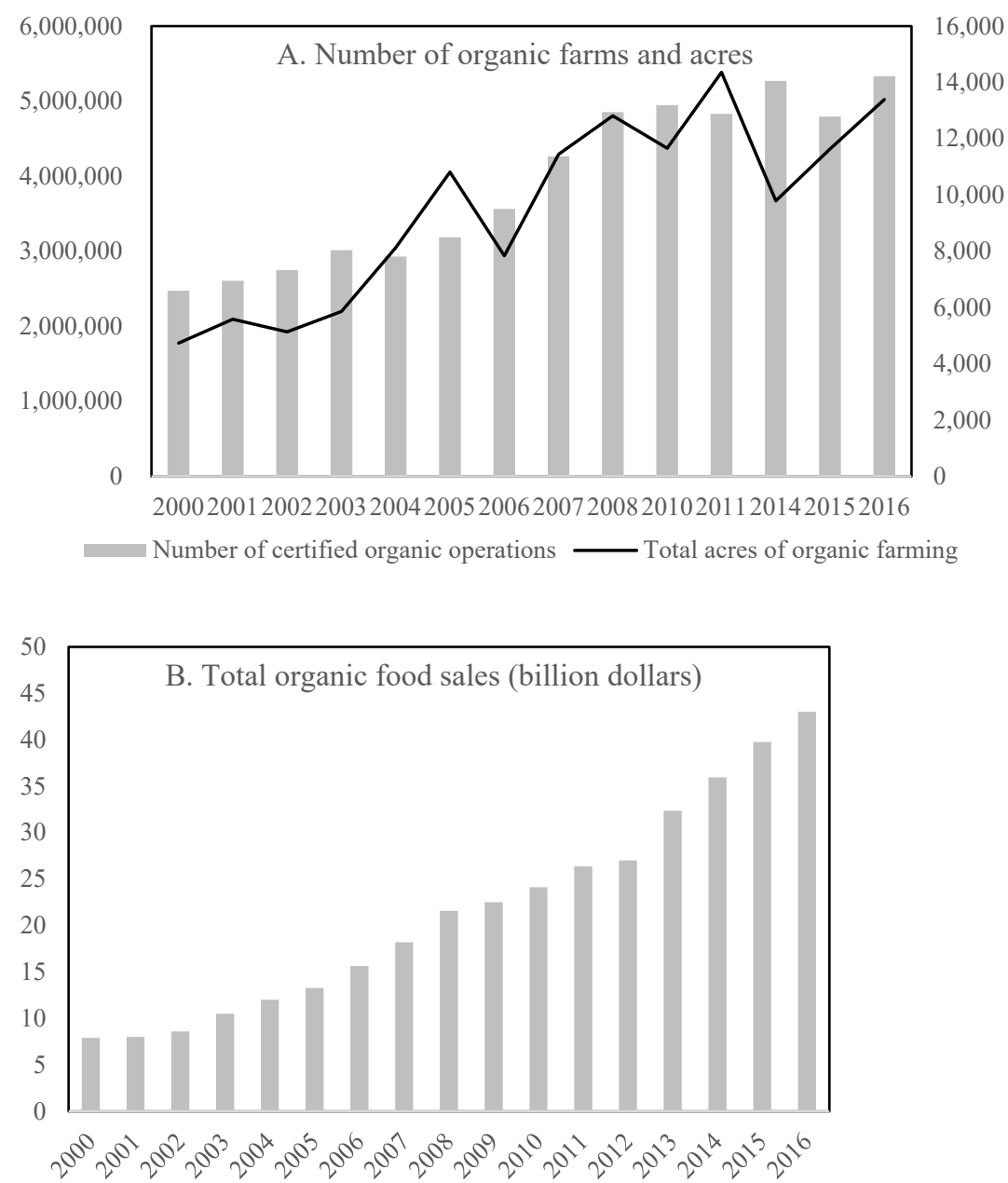

Figure 1. The trend of organic farms, production acres, and sales in the U.S.

While the domestic supply of organic products seems to have stagnated in most recent years, the demand for organic agricultural products has increased consistently over the past decades. Plot B in Figure 1 shows that total organic food sales in the U.S. in the year 2000 were valued at about 7.9 billion dollars, but sales reached 43 billion dollars in 2016; total organic food sales are expected to continue to increase in the future [31]. As more and more consumers in the U.S. become aware of the benefits of organic food [32] such as food safety, friendliness to the environment, respect for animal rights, and stimulation of the rural economy, they would be more willing to buy organic products instead of regular farm commodities. A survey by the Organic Trade Association found that more than $84 \%$ of U.S. households purchase organic food sometimes while $45 \%$ buy organic agricultural products at least once a month. The rapidly growing demand for organic food has imposed great pressure on the U.S. organic sector which, as shown in plot A, is struggling to meet the needs of U.S. consumers.

\subsection{Organic Farming Geographic Distribution}

In addition to the fact that the fast-paced demand growth has led to organic food supply shortages in the supply chain [17], Figure 2 shows that the uneven distribution of organic farming across states may hinder organic product supply in certain areas and also deprive a vast number of farms in some areas of the opportunity of higher farming profitability. The darker the color a state has in Figure 2, the larger is the size of a state's organic farm industry. 


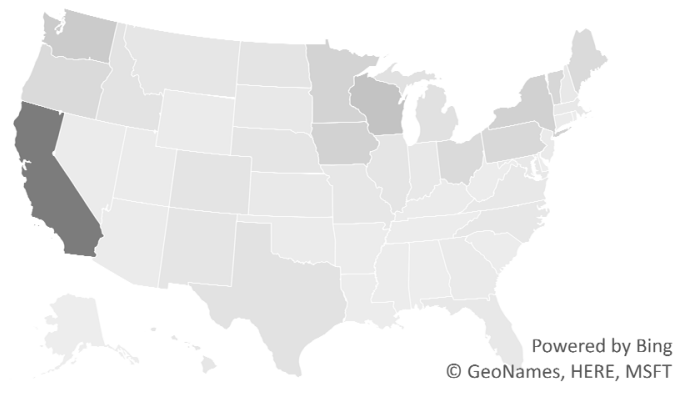

Number of organic farms

$$
0.00 \quad 2,016.73
$$

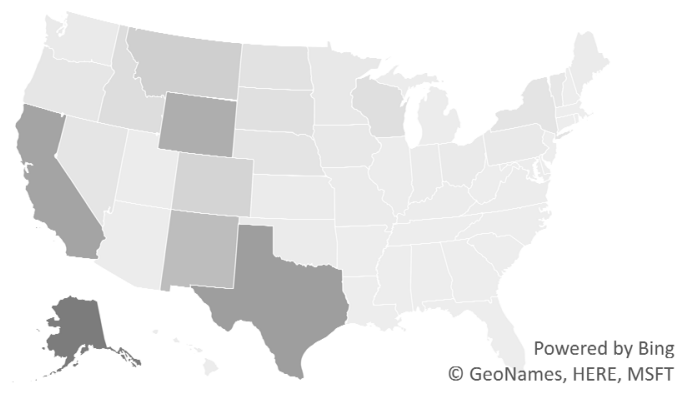

Organic pasture acres

$$
10.00 \quad 288,242.22
$$

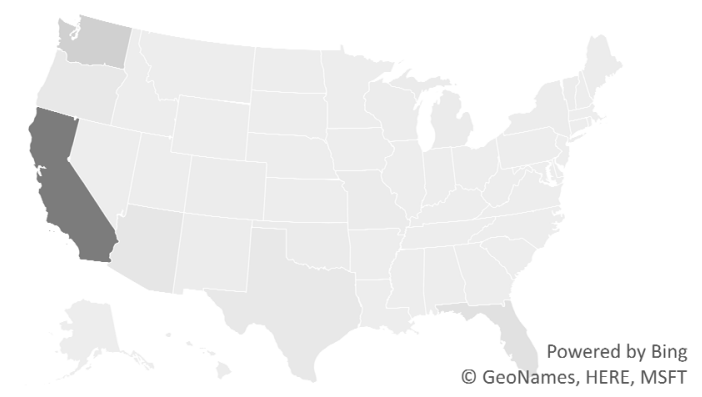

Organic fruit acres

0.00

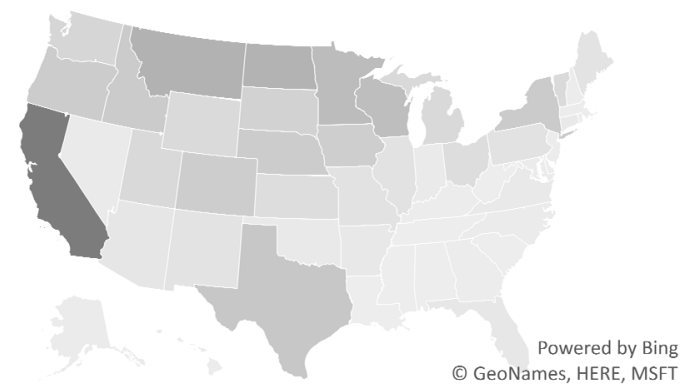

Organic crop acres

$$
98.83 \quad 266,874.02
$$

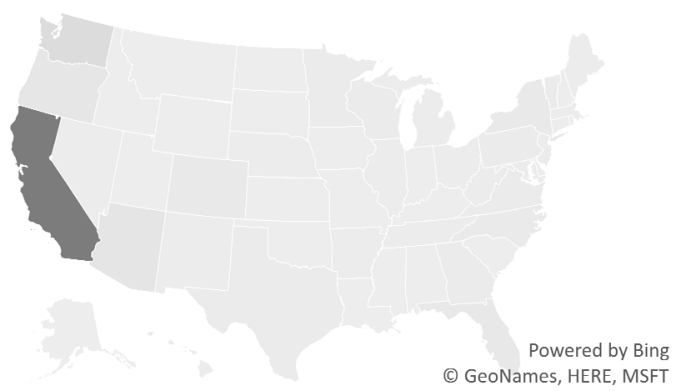

Organic vegetable acres

7.36

$59,667.27$

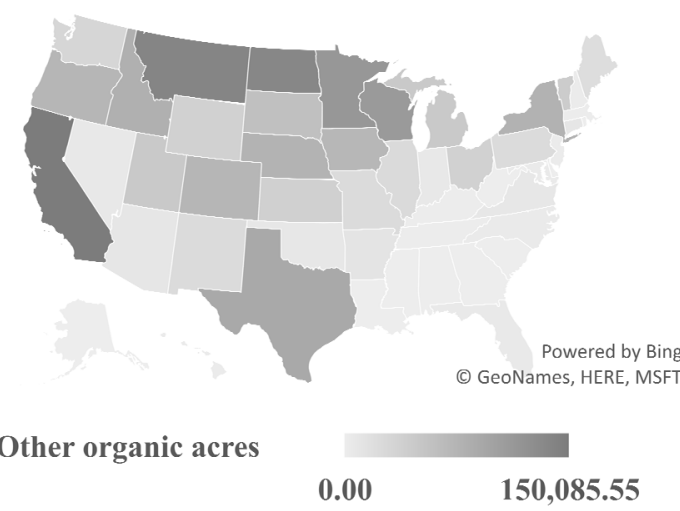

Figure 2. The distribution of organic farming across the U.S.

As can be seen from the first two top plots, most of the organic production in the U.S. is concentrated in the Western U.S. especially in California, while some states in the Midwest and Southwest such as Montana and Texas also show a booming organic sector. On the other hand, the development of the organic farm sector in the Southwestern U.S. is lagging. The mean organic agricultural acres of the Southeastern region were about 3145 acres, which was only about $1.2 \%$ of the total organic acres in California. The uneven distribution of organic farming across states and regions was also found by Taus, OgnevaHimmelberger and Rogan who investigated agglomeration effects in the organic farm sector in the U.S. [17]. Other plots in Figure 2 present different types of agricultural products, also showing similar results - that farmers in the Southeastern regions may not equally enjoy the benefits of the booming organic sector.

Organic production in the U.S. faces other challenges as well. First, U.S. organic producers and manufacturers must cope with the impacts of fluctuating market conditions, 
particularly the impact of a weaker U.S. economy. The growing demand for organic food is partly based on the improved income of the U.S. household [33] and consumers are willing to pay price premiums for organic products [34]. However, many uncertainties such as international trade disputes, recession, natural disasters, and a series of regulatory policies may disrupt the demand of consumers. Second, even though many U.S. consumers are buying organic products, the industry is slow in exploring and reaching out to new or infrequent buyers. Third, organic producers nowadays also must cope with the competition from new labels such as "locally grown". To promote the production of organic agriculture, the U.S. Congress boosted grant funding for organic agricultural research through USDA and initiated a certification cost-share program to help enhance the competitiveness of the organic sector. However, the impact of public funding is little known so far, due to limited studies. This study tries to fill this gap by specifically examining the impact of research funding by USDA and state governments.

\subsection{Conceptual Framework}

The main purpose of this part is to discover the important factors affecting organic agriculture or general agricultural production by referring to the previous literature, and to put forward some hypotheses, so as to provide the basis for the empirical research and analysis. The main influencing factors are divided into four categories, which are macroeconomic factors, policy factors, demographic factors, and agricultural input factors.

\subsubsection{Macroeconomic Factors}

The macroeconomic factor studied in this paper is median household income. It refers to the concept of median in statistics to measure the income level of ordinary people in a certain area. Compared with the per capita income, the median income is closer to the actual living standard of ordinary people.

Farming households with higher income gain in absolute terms more from organic agriculture as they cultivate more land [35]. Nonfarm income provides households with a form of insurance against the risks of farming, and thus enables them to adopt new production methods and raise output [36]. In this study, our hypothesis is:

Hypothesis 1 (H1). A higher median household income has a positive and significant effect on local organic farming development.

\subsubsection{Policy Factors}

The policy factors studied in this paper are USDA approved grant, state approved grant and direct government transfer. USDA approved grant and state approved grant monetary or nonmonetary assets are provided by the state or government free of charge. Direct government transfer refers to the government's expenditure on social welfare, insurance, poverty relief and subsidies, which is realized through the redistribution of income among different members of society. Political factors directly and indirectly affect agricultural production, and indirect political influence usually affects agricultural production through funds, research cooperation, and subsidies [37,38]. Dimitri and Oberholtzer considered that the main determinant for the fast growth of organic agriculture in the Czech Republic is subsidies on the part of the state [39]. Our hypothesis is:

Hypothesis 2 (H2). Support from the government including research funding and direct transfer have a positive and significant effect on local organic farming development.

\subsubsection{Demographic Factors}

Demographic conditions are conducive to the production and development of organic farming $[40,41]$. The demographic factors studied in this paper are percent white, percent Hispanic, percent noncitizen, male farmers' ratio, mean farmer age, and total population. Percent white, percent Hispanic, and percent noncitizen respectively represent the propor- 
tion of white, American, and noncitizens in the total population of the United States. Male farmers' ratio and mean farmer age reflect the impact of gender differences and individual age on organic production. Gender is an important determinant of agricultural production. According to Adebiyi and Okunlola, in Nigeria, females do more in off-farm activities such as selling agricultural products, storing, and packing them [42]. This indicates that males paid attention to farm work and could better adopt farm rehabilitation techniques, and obtain inputs for sufficient production. In addition, age can be related to experience of farming; as age increases farm experience increases and then input adoption as well as production may increase up but perhaps up to a certain age limit [43,44]. Total population reflects the size of consumer groups from the demand side. The evolution of organics relies on the conversion of consumers to organic food [7]. Our hypothesis is:

Hypothesis 3 (H3). A higher share of white population, a higher male ratio in the farmer population, and a larger total population have a positive and significant effect on local organic farming development; a higher share of noncitizens and an older age of farmer population both have a negative and significant effect on local organic farming development.

\subsubsection{Agricultural Input Factors}

The agricultural input factors studied in this paper are farm size and total farm labor. Farm size indicates the scale of organic production. It is misleading to generalize about the existence of an inverse relationship between farm size and productivity across all farming systems and regions [45]. Rather than an inverse relationship, where productivity falls as farm size rises, a U-shaped relationship was found. For farms up to about 200 hectares, efficiency did fall as farm size rose, but beyond this size it started to rise again [46]. Total farm labor reflects labor input in organic agricultural production. In Palestine, Abugamea revealed that a $100 \%$ increase in labor will result in a $38.1 \%$ increase in agricultural production [47]. Byerlee et al. posited that there is higher agricultural production and growth per worker where there is abundant labor force [48]. Our final hypothesis is:

Hypothesis 4 (H4). Larger farm size and farm labor population have a positive and significant effect on local organic farming development.

\section{Data and Method}

\subsection{Data Sources}

The data used in this research come from multiple sources. The 2000-2016 state-level organic production data such as the number of organic farms, the total acres of organic crop and pastureland, as well as the total acres of organic vegetable, fruit, and other crops are available from the Certified Organic Survey provided by the USDA. Year 2016 is chosen because it is the latest year in which the organic production data are available. The data for some years are missing because the survey was not conducted in these years, but this would not affect the cross-sectional analysis of this study.

Variables included in the model provide information on agricultural production conditions, societal and economic conditions, research funding, demographic characteristics, and government policies. The data on agricultural research funding are from USDA's Current Research Information System. Economic indicators such as median household incomes are obtained from the Census Bureau's Small Area Income Poverty Estimates. Agricultural industry indicators such as the average farm size, male farmer ratio, and mean farmer's age are from the Census of Agriculture. Demographic information such as the Hispanic and white population shares and the total population is from the U.S. Census Bureau's Annual Estimates of the Residential Population. Data on total farm workers are collected from the Quarterly Census of Employment and Wages.Direct government payment for agriculture is obtained from the Farm Income and Wealth Statistics. Summary statistics for the dependent and independent variables used in this study are shown in Table 1. 
Table 1. Summary statistics: state level.

\begin{tabular}{|c|c|c|c|c|}
\hline Variable & Mean & Std. Dev. & Min & Max \\
\hline & \multicolumn{4}{|c|}{ A. Dependent variables } \\
\hline Total number of organic farms & 191.39 & 333.43 & 0 & 2887 \\
\hline Total organic crop acres & $38,992.17$ & $57,697.94$ & 0 & $497,082.7$ \\
\hline Total organic pasture acres & $28,554.32$ & $100,398.10$ & 0 & $1,460,000$ \\
\hline Total organic vegetable acres & 2155.99 & 9537.95 & 0 & $100,336.5$ \\
\hline Total organic fruit acres & 1952.94 & 9057.01 & 0 & $101,581.4$ \\
\hline \multirow[t]{2}{*}{ Total other organic acres } & $35,157.86$ & $48,418.21$ & 0 & $361,557.4$ \\
\hline & \multicolumn{4}{|c|}{ B. Independent variables } \\
\hline Median household income & $46,277.65$ & 8063.05 & 30,187 & 70,482 \\
\hline USDA approved grant & $22,528.08$ & $26,087.53$ & $\begin{array}{c}0 \\
0\end{array}$ & 143,664 \\
\hline State approved grant & $25,383.37$ & $22,605.61$ & 0 & 138,647 \\
\hline Farm size & 560.09 & 697.01 & 56 & 3750 \\
\hline Percent white & 74.01 & 15.09 & 22.94 & 96.41 \\
\hline Percent Hispanic & 8.23 & 9.04 & 0.63 & 43.17 \\
\hline Total farm labor & $23,650.11$ & $55,020.12$ & 760 & 391,950 \\
\hline Percent noncitizen & 4.56 & 3.31 & 0.16 & 17.02 \\
\hline Male farmers ratio & 0.48 & 0.01 & 0.45 & 0.51 \\
\hline Mean farmer age & 36.31 & 2.91 & 24.94 & 47.67 \\
\hline Total population & $5,923,384$ & $6,531,182$ & 494,423 & $3.77 \times 10^{7}$ \\
\hline Direct government transfer & $321,783.4$ & $369,826.3$ & 1250 & $2,485,880$ \\
\hline $\mathrm{N}$ & 550 & & & \\
\hline
\end{tabular}

Notes: USDA denotes United State Department of Agriculture.

\subsection{Multivariate Analytical Model}

Yamamoto et al. used a multiple regression analysis to assess the impact of climate change on principal agriculture production areas [49]. Zeru employed multiple regression analysis to examine the simultaneous effects of several independent variables on the dependent variable, total agricultural outputs [50]. The basis of this model is the OLS regression, which is a common method for testing the correlation of variables [51-53]. This study examines the determinants of general organic production of specific crops at the state level using information from all states in the U.S. and multiple years of 2000-2016. The research aims to answer the question of which determinants are significant for organic farming by employing a multivariate regression framework. The specification of the multivariate model is constructed as follows:

$$
\text { Organicfarming }_{s t}=\alpha+\beta_{1} X_{s t}^{\prime}+\gamma_{s}+\delta_{t}+\varepsilon_{s t}
$$

where Organicfarming ${ }_{s t}$ denotes the organic farming outcomes in the U.S. and $X_{s t}^{\prime}$ is a vector of observables that have been shown in Table 1. As can be seen from Table 1, variables containing personal biases have been controlled. It is important to control personal traits in the empirical analysis, because these traits may affect the development of organic farming in the regression. $\beta_{1}$. is a vector of coefficients that shows the estimated impacts of different factors on organic farming outcomes. $\gamma_{s}$ and $\delta_{t}$ are state and year fixed effects that can control for the unobservable confounding factors that do not change across years and states. By including state and year fixed effect, the model can provide more accurate estimates for the impacts of each factor in the regression. Given the concern that the outcome variables examined in this study could be correlated, we introduce the seemingly unrelated estimation to Equation (1) to address serial correlation issues across error terms of regressions for various outcomes.

The state-level analysis offers multiple advantages for the study. First, it provides the most recent updated information for the organic sector in the U.S. by looking at the years of data that cover a long period. Second, instead of only focusing on one state or region, an investigation at the state level could offer a more comprehensive perspective on the current status of U.S. organic agriculture. An understanding of the organic industry at the macro-level is as important as the analysis of individual farms' organic adoption decisions. Third, a study at the state level could be compared to other studies in the future with a similar topic. Other agricultural research can easily compare the results of this study with their work to check if the determinants of organic farming in the U.S. have changed 
over time and if some determinants become more prominent and important as the U.S. economy and society evolve. The estimates of this study offer important implications for the policymaker, relevant stakeholders, and other agricultural scholars who are interested in organic production issues.

\subsection{Research Framework Flowchart}

Figure 3 presents the research flowchart framework of this study. As the organic commodity market develops and integrates across the U.S., there is a greater demand for a comprehensive understanding of the key factors' impacts on organic farming, and if they would effectively promote the organic supply in the U.S. This study fills in the research gap by looking at the macro-level factors and it will complement previous studies that focused on similar topics by looking at the farm level. The multivariate analytical framework with multiple year data enables this study to examine whether a series of factors can effectively promote organic farming and by how much. Meanwhile, a specific analysis of the organic farming sector for different crops would further corroborate the main results. This study provides evidence using state-level observations and a robust econometric method to further support the findings of relevant literature. Moreover, it also carries insightful policy implications for the construction and further promotion of the organic market that currently lags behind demand in the U.S.

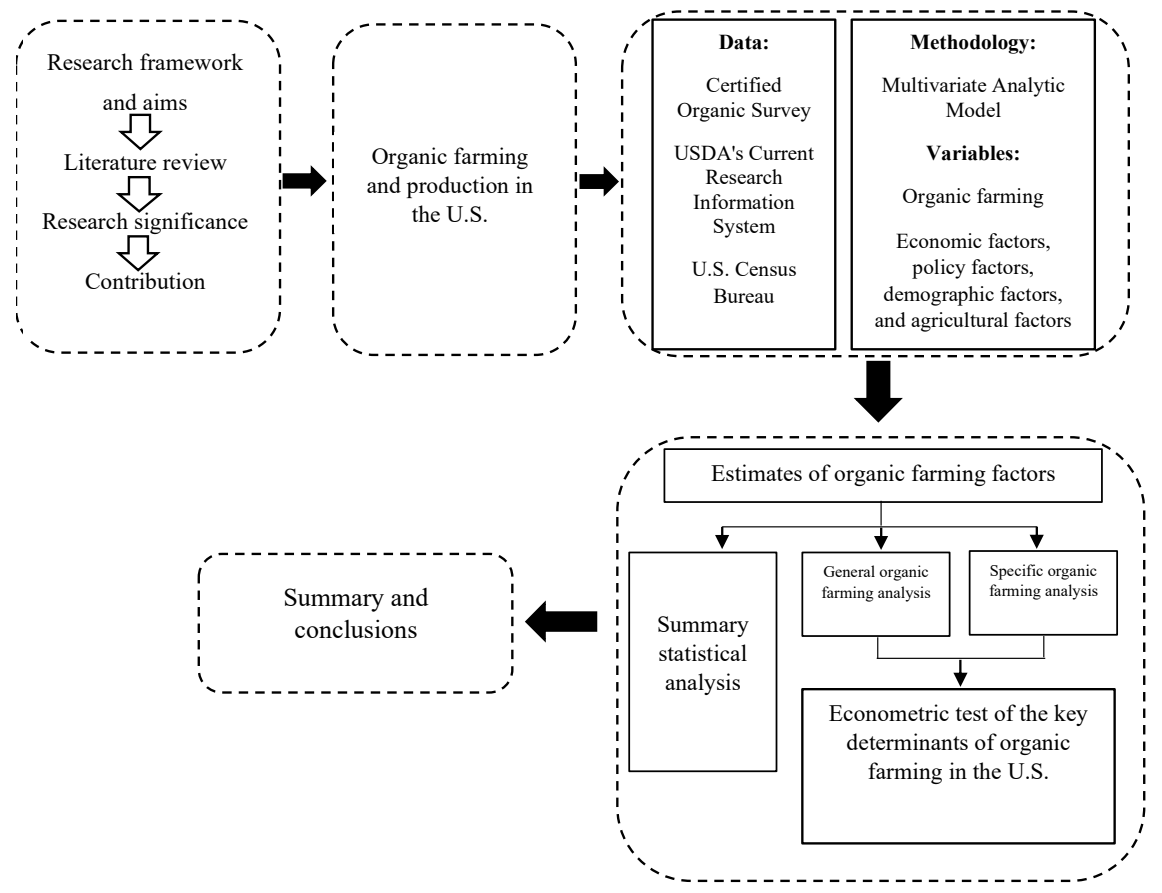

Figure 3. The framework of research.

\section{Empirical Results and Discussion}

This section first examines the determinants that could significantly affect general organic production in the U.S. such as the number of organic farms and the total acres of organic crop and pastureland. The section then focuses on specific crops by investigating the production determinants of organic vegetables, fruits, and other crops.

\subsection{General Organic Crop Estimation}

Results in Table 2 show that several variables appear to impact the number of organic farms at the state level. Though there is little impact from the state approved funding on the number of organic farms, the USDA approved funding is shown to significantly increase the number of organic farms. The Agricultural Act of 2008 in the U.S. increased the mandatory spending on agriculture by a total of approximately 100 million dollars with two major 
programs including the National Organization Certification Cost-Share Program (NOCCP) and Organic Agricultural Research and Extension Initiative (OAREI). The Agricultural Act of 2014 has further expanded the funding to help organic producers and handlers with the organic certification cost and increased the total funding to 57.5 million dollars for the NOCCP. Meanwhile, the Act also increased the total organic research funding to 100 million dollars. These farm Acts are passed to support and promote the development of organic production to meet the increasing demand for organic commodities in the U.S. The statistically significant estimate of USDA approved funding shows that these policies could greatly help the expansion and stimulate the growth of the organic farming sector. The result is consistent with previous research that emphasizes the importance of research that could significantly contribute to solving the challenges of organic production [54-56]. Wheeler found that R\&D funding would increase the share of organic farming of total agricultural land by approximately $1.73 \%$ [57]. Halpin, Daugbjerg and Schvartzman examined the agricultural research funding system in the United Kingdom and claimed that increased organic agricultural research would bring much higher supplies of organic products to meet the increased demand [58]. The reasons for success of organic farming in the individual countries of Europe are various, and the funding of research and research institutions are important factors. For example, there is the Nordic network; in the German language region a scientific conference takes place every two years; and in Italy there is the network of GRAB-IT [59]. From the view point of India, encouragement for organic agriculture by means of subsidies, etc. by the government is much needed [60]. Growth and development of the agricultural sector has been on the agenda of policy makers. $R \& D$ expenditure has been one of the policy avenues implemented by the government of Iran [61]. This study provides empirical findings to support these studies.

Table 2. Estimates of the determinants of organic farms, organic pastureland, and organic crop land in the U.S.

\begin{tabular}{cccc}
\hline & $\begin{array}{c}\text { Number of Organic } \\
\text { Farms }\end{array}$ & Organic Pasture Acres & Organic Crop Acres \\
\hline Median household & $\mathbf{( 1 )}$ & $\mathbf{( 2 )}$ & $\mathbf{( 3 )}$ \\
income & & & \\
& 0.013 & 1.907 & 0.138 \\
USDA approved grant & $(0.007)$ & $(2.695)$ & $(1.224)$ \\
& $0.004^{* *}$ & -0.86 & 0.424 \\
State approved grant & $(0.002)$ & $(0.689)$ & $(0.218)$ \\
& -0.002 & -1.049 & -0.281 \\
Farm size & $(0.002)$ & $(0.688)$ & $(0.308)$ \\
& 0.001 & -110.135 & 3.018 \\
Percent white & $(0.065)$ & $(68.401)$ & $(15.646)$ \\
& $92.312^{* * *}$ & $-18,649.52$ & 7325.317 \\
Percent Hispanic & $(26.230)$ & $(15,803.997)$ & $(6076.741)$ \\
& $155.664^{* * *}$ & $-32,100.103$ & 6564.899 \\
Total farm labor & $(50.360)$ & $(28,889.244)$ & $7.493 .974)$ \\
& $0.040^{* * * * *}$ & $(1.482)$ \\
Percent noncitizen & $(0.004)$ & $12.166 * * *$ & $-10,190.716 * *$ \\
& $-38.850^{* *}$ & $(2.618)$ & $(4591.177)$ \\
Male farmers ratio & $(18.591)$ & $-31,028.732 * *$ & $-476,101.266$ \\
& 133.098 & $(12,993.196)$ & $(674,257.097)$ \\
Mean farmer age & $(1294.023)$ & $-825,116.881$ & 292.75 \\
& -4.705 & $(588,665.062)$ & $(786.098)$ \\
Total population & $(3.760)$ & 594.465 & $0.042 * * *$ \\
& $0.001^{* *}$ & $(1533.958)$ & $(0.006)$ \\
Direct government & $(0.000)$ & 0.033 & 0.015 \\
transfer & 0.000 & $(0.031)$ & $(0.010)$ \\
$\mathrm{N}$ & $(0.000)$ & 0.023 & 332 \\
$\mathrm{R}^{2}$ & 332 & $(0.013)$ & 0.961 \\
\hline
\end{tabular}

Notes: USDA denotes the United States Department of Agriculture. Robust standard errors are reported in the parentheses. ${ }^{* *} p<0.05$, and ${ }^{* * *} p<0.01$. 
Some demographic factors such as the share of the Hispanic and white population in a state are found to impose a positive impact on the growth of organic farming, while a higher share of noncitizens is associated with lower organic farms' numbers. Hartman Group surveyed consumer attitudes and behaviors toward organic food and found that Hispanics were more likely to purchase organic products [62]. Stevens-Garmon, Huang and Lin also pointed out that in the U.S. there is a trend that many organic consumers are white and have young children [63]. In addition, they found that among all demographic characteristics, race is the most correlated with organic expenditure. Policymakers could guide the organic farming industry in promoting their products to different groups and may adopt different strategies and advertisements to attract more diverse consumers with different ethnicities. Anderson et al. found that the odds ratio for the age of the primary farm operator indicates that with each additional year of age, the probability that a farmer will adopt organic methods decreases, which is consistent with the conclusion in this study [19]. Ladvenicová and Miklovičová concluded that farm size has a negative impact of $170.3 \%$ on output per hectare foran increase about $1 \%$ in area [64], which is inconsistent with the conclusion in this study.

As the size of the total population increases, there would also be an increase the number of organic farms. Kostandini, Mykerezi, and Tanellari used the county level organic farming data and suggested that an increase of local population would increase the number of organic farms by 0.013 [22]. This is expected because a larger population suggests a larger consumer base which would provide the local organic growers with a stable demand for their products. The estimates suggest that policymakers should be more aware of the importance of cultivating a large and stable consumer group to ensure the steady development of local organic farming. One more factor that would affect the number of organic farms is the total number of farm workers in a state. Even though many sectors in agriculture nowadays have adopted mechanization, the organic production sector may be still labor-intensive due to its unique agronomic practices that prevent the use of many chemical and polluting inputs. As a result, abundant labor is an essential factor for an organic farm to sustain itself and make a profit [65]. Lohr and Park found that an expansion of farm labor employment would raise rates of return to organic production and therefore would increase the organic acreages [66]. Schneeberger, Darnhofer and Eder further pointed out that farm labor, including family and hired labor, are essential for organic farms due to their labor-intensive nature [67].

However, multiple factors nowadays seem to jeopardize a stable supply of farm labor to organic agriculture in the U.S., such as reduced migration from other countries (such as Mexico), more stringent immigration policies across states, and a notable shift of labor from the farm sector to other sectors with higher salaries. The estimates in Table 2 suggest that farm labor is positively connected to the expansion of the organic farming sector and that a labor shortage that may happen in the future may become a critical issue for organic farming in the U.S. Aubert and Enjolras found that labor appears as a key factor insofar as organic farming practices differ from conventional farming, with several implications in terms of activities and marketing channels $[65,68]$.

The estimates in column (2) and (3) report the determinants of organic pasture and crop land. We find fewer significant determinants than for the number of organic farms. However, we still find that the total population size and noncitizen population would increase and decrease the total acres of organic crops, respectively. Pasture and crop have different features, which leads to the different influence of various factors on them, and the degree of influence is also different. In temperate and arid zones, animal husbandry plays an important role in the recycling of nutrients, while it is less emphasized in the humid tropics. However, fruit growing is more popular in the humid tropics. Jingzhong et al. found in the past three years, the herds in Sanggang village in China have been growing steadily and the development of these herds is also driven by labor investments [69]. Zegler et al. pointed out that prioritizing management of residual height and improved legume and non-improved grass cover are critical for high milk production from organic pastures 
in the Upper Midwest [70]. Demographic aspects such as age of household head affect only infra-specific diversity of cereals [71]. Moreover, the availability of farm labor is found to be important for all three dependent variables [72], which, as a result, further emphasizes the importance of maintaining a stable and reliable farm worker population to promote organic production in the future.

\subsection{Specific Organic Crop Estimation}

One of the contributions of this study is that we study the determinants of organic production by different types of crops. We examine vegetable and fruit crops separately from other crops because they are in general less mechanized and labor-intensive than other crops. Column (1) Table 3 shows the key determinants of organic vegetable production. As can be seen, they share some similarly significant estimates as those in Table 2. USDA grant funding positively affects the organic vegetable acres while the state approved funding is not statistically significant. It appears that USDA is playing an important role in promoting the production of vegetables, which are the organic products most seen in people's daily lives in the U.S. Organic vegetables also are found to have their target population, as a higher percentage of the white and Hispanic populations increases the organic vegetable acres. Dubowitz et al. found that the black population consumed 0.42 fewer daily servings of fruit and vegetables combined and 0.50 fewer daily servings of vegetables than did whites [73]. The estimates in column (1) Table 3 again indicate that increased total farm worker population promotes the expansion of organic vegetable production, and this is particularly true for labor-intensive vegetables such as lettuce and melons. This result is consistent with Jansen et al. and Hassan et al. [74,75]. Jansen et al. suggested that labor is a factor limiting vegetable production enterprises according to the result of the negative correlation between farm size and cropping intensity [75]. Hassan et al. concluded that a positive relationship has been achieved between the amount of wheat production and the cultivated area of wheat (estimated per feddan), the rates of rainfall (mm/year), and the number of workers [75]. Estimates in column (2) show that the total acres of organic fruits are affected by the total number of farm workers and the total population size in a state. Mpawenimana has investigated the socio-economic factors affecting the production of bananas in Rwanda; the results showed that acreage of land has a positive relationship with output [76]. However, we do not see factors such as USDA grant funding affecting organic fruit production. The reasons could be that USDA research puts more emphasis on organic vegetables or that the funding for organic fruit does not have a similarly prominent influence like that on organic vegetables. This is an interesting topic that could be taken up in future research that specifically examines how public-funded research could affect organic farming.

Finally, it can be seen from column (3) Table 3 that USDA funding, the total farm worker population, and the total population size in a state might positively affect the organic production of other crops. These results are consistent with Wheeler, Abugamea and Lamine \& Bellon, respectively $[7,47,57]$. Policymakers who would like to expand the production of other crops such as grain and feed crops should pay more attention to cultivating a stable farm labor pool, expanding the consumer base, and improving the use of research funding as some efficient measures to increase the production of other organic crops. 
Table 3. Estimates of the determinants for organic vegetable land, fruit crop land, and other organic lands in the U.S.

\begin{tabular}{|c|c|c|c|}
\hline & $\begin{array}{c}\text { Organic Vegetable } \\
\text { Acres }\end{array}$ & Organic Fruit Acres & Organic Other Acres \\
\hline & (1) & (2) & (3) \\
\hline \multirow{2}{*}{$\begin{array}{l}\text { Median household } \\
\text { income }\end{array}$} & 0.155 & 0.013 & 0.014 \\
\hline & $(0.165)$ & $(0.067)$ & $(1.141)$ \\
\hline \multirow{2}{*}{$\begin{array}{l}\text { USDA approved } \\
\text { grant }\end{array}$} & $0.074^{* * *}$ & -0.052 & $0.505^{* * *}$ \\
\hline & $(0.028)$ & $(0.054)$ & $(0.185)$ \\
\hline \multirow[t]{2}{*}{ State approved grant } & -0.012 & -0.095 & -0.078 \\
\hline & $(0.032)$ & $(0.073)$ & $(0.275)$ \\
\hline \multirow[t]{2}{*}{ Farm size } & -3.297 & 1.558 & 9.016 \\
\hline & $(4.968)$ & $(1.275)$ & $(13.694)$ \\
\hline Percent white & $\begin{array}{c}3182.635^{* * *} \\
(972.070)\end{array}$ & $\begin{array}{c}190.283 \\
(346.819)\end{array}$ & $\begin{array}{c}6390.136 \\
(5350.674)\end{array}$ \\
\hline Percent Hispanic & $\begin{array}{c}5217.981^{* * * *} \\
(1993.801)\end{array}$ & $\begin{array}{c}58.418 \\
(946.138)\end{array}$ & $\begin{array}{c}4730.278 \\
(8814.128)\end{array}$ \\
\hline Total farm labor & $\begin{array}{l}0.944^{* * *} \\
(0.319)\end{array}$ & $\begin{array}{c}1.033^{* * *} \\
(0.273)\end{array}$ & $\begin{array}{l}4.817^{* * *} \\
(1.238)\end{array}$ \\
\hline Percent noncitizen & $\begin{array}{l}-239.711 \\
(446.338)\end{array}$ & $\begin{array}{l}-530.005 \\
(496.138)\end{array}$ & $\begin{array}{l}-5082.976 \\
(3438.659)\end{array}$ \\
\hline Male farmers ratio & $\begin{array}{c}39,707.497 \\
(34,826.788)\end{array}$ & $\begin{array}{l}-30,848.926 \\
(27,259.720)\end{array}$ & $\begin{array}{l}-360,380.833 \\
(661,125.381)\end{array}$ \\
\hline Mean farmer age & $\begin{array}{c}147.244 \\
(112.932)\end{array}$ & $\begin{array}{c}24.128 \\
(84.081)\end{array}$ & $\begin{array}{l}-39.016 \\
(731.546)\end{array}$ \\
\hline Total population & $\begin{array}{l}-0.005 \\
(0.004)\end{array}$ & $\begin{array}{c}0.005^{* * *} \\
(0.002)\end{array}$ & $\begin{array}{c}0.031^{* * *} \\
(0.005)\end{array}$ \\
\hline \multirow{2}{*}{$\begin{array}{l}\text { Direct government } \\
\text { transfer }\end{array}$} & -0.001 & 0 & 0.012 \\
\hline & $(0.001)$ & $(0.001)$ & $(0.009)$ \\
\hline $\mathrm{N}$ & 331 & 328 & 328 \\
\hline $\mathrm{R}^{2}$ & 0.996 & 0.96 & 0.917 \\
\hline
\end{tabular}

Notes: USDA denotes the United States Department of Agriculture. Robust standard errors are reported in the parentheses. ${ }^{* * *} p<0.01$.

\section{Summary and Conclusions}

This research examines the determinants of organic farming at the state level using data collected from multiple sources. The results show that the scale of organic production may change according to the ethnicity composition in a state as well as the share of noncitizens in a state. Some other factors such as median household income and direct government payments are not statistically significant in this study. Moreover, we find that the key determinants of organic farming differ for different crops.

Most importantly, the results provide suggestive evidence showing that there is a positive relationship between USDA funding and organic farming development. This indicates that it could be possible for USDA research support to promote and encourage organic production and supply to a notable extent. However, we would like to note that the cross-sectional analysis conducted in this study cannot help build a causal link between USDA funding and organic farming expansion. A quasi-natural experiment analysis could help alleviate such concerns as more data become available in the future.

Another critical factor that is found to play an important role in organic farming is the total number of farm workers. As the organic farming sector continues to expand, it will increase the need for more workers. However, the supply of farm workers is expected to further decrease [77] as more stringent immigration policies are adopted. Those immigration policies may severely undermine the labor pool of organic agriculture in the U.S. and notably increase the labor cost for organic farming, which in turn would 
increase the prices of organic commodities, decrease the profit margins of organic farms, and diminish the competitiveness of the U.S. organic agricultural industry. Organic farming policymakers need to cooperate with policymakers in immigration and other sectors to ensure the labor sustainability of the organic sector.

This study examines data on the growth of organic farming at the state level that includes all U.S. states and spans almost two decades. The results of this study can be insightful for the state sector, the farm sector, and organic farmers that would like to have a more comprehensive and clearer vision of the factors that might affect organic production in the country. First, the state sector should deal with the relationship between agricultural development and immigrants. For example, giving appropriate benefits to the immigrant population might increase the labor force and consumers needed for the development of organic farming. Second, USDA should increase financial support for organic farming, especially in Southwestern U.S. where organic farming is relatively backward. Third, the organic farmers themselves need to make full use of government funds and establish an appropriate wage incentive system to improve the enthusiasm of the farm workers in the case of labor shortage. Moreover, this study also provides important implications for other countries that seek to promote domestic organic production. Finally, this study offers insights for more research of this genre as the organic product market continues to grow and expand.

We would like to note some limitations of this study. First, some information such as the prices of organic products and other relevant market conditions are not included in the model due to data unavailability. Research that has access to such information in the US or other countries should consider controlling these covariates. Second, as mentioned before, the cross-sectional data structure of this study constrains the investigation of a causal link between different determinants and organic production. As more longitudinal data or quasi-natural experiments become available, research may establish a robust causal relationship in the future. Third, even though state-level data bears many advantages, it may lack the details that can be captured by the county level or farm-level data. One solution to this is to combine the state level, county level (e.g., Census of Agriculture countylevel data), and farm level (e.g., Agricultural Resource Management Survey) information to evaluate the organic farming industry in the future.

Author Contributions: Conceptualization, Y.H.; data curation, T.L.; formal analysis, Y.H., T.L. and J.H.; methodology, Y.H.; software, T.L. and J.H.; writing—original draft, T.L. and J.H.; writing—review and editing, Y.H. All authors have read and agreed to the published version of the manuscript.

Funding: This research received no external funding.

Institutional Review Board Statement: Not applicable.

Informed Consent Statement: Not applicable.

Data Availability Statement: Not applicable.

Conflicts of Interest: The authors declare no conflict of interest.

\section{References}

1. Badgley, C.; Moghtader, J.; Quintero, E.; Zakem, E.; Chappell, M.J.; Avilés-Vázquez, K.; Samulon, A.; Perfecto, I. Organic agriculture and the global food supply. Renew. Agric. Food Syst. 2007, 22, 86-108. [CrossRef]

2. Bacenetti, J.; Fusi, A.; Negri, M.; Bocchi, S.; Fiala, M. Organic production systems: Sustainability assessment of rice in Italy. J. Agric. Ecosyst. Environ. 2016, 225, 33-44. [CrossRef]

3. Marasteanu, I.J.; Jaenicke, E.C. Economic impact of organic agriculture hotspots in the united states. Soc. Sci. Electron. Publ. 2018, 34, 501-522.

4. Rocha, H.O.; Sternberg, R. Entrepreneurship: The role of clusters theoretical perspectives and empirical evidence from Germany. Small Bus. Econ. 2005, 24, 267-292. [CrossRef]

5. Graham, D.J.; Kim, H.Y. An empirical analytical framework for agglomeration economies. Ann. Reg. Sci. 2008, 42, 267-289. [CrossRef]

6. Padel, S. Conversion to organic farming: A typical example of the diffusion of an innovation? Sociol. Rural. 2010, 41, 40-61. [CrossRef] 
7. Lamine, C.; Bellon, S. Conversion to organic farming: A multidimensional research object at the crossroads of agricultural and social sciences. A review. Agron. Sustain. Dev. 2009, 29, 97-112. [CrossRef]

8. Laure, L.; Nauges, C. Technical efficiency and conversion to organic farming: The case of France. Eur. Rev. Agric. Econ. 2017, 2, 227-253.

9. Koesling, M.; Flaten, O.; Lien, G. Factors influencing the conversion to organic farming in Norway. Int. J. Agric. Resour. Gov. Ecol. 2008, 7, 78-95. [CrossRef]

10. Ferruh, I.; Tayfun, C.; Goksel, A. Factors affecting the adoption of the organic dried fig agriculture system in Turkey. J. Appl. Sci. 2007, 7, 748-754.

11. Organic Trade Association. US Organic Industry 2019 Survey. Available online: https://ota.com/what-ota-does/marketanalysis/organic-industry-survey/organic-industrysurvey (accessed on 12 December 2019).

12. Quality Assurance International. 2018 U.S. Farm Bill a Win for the Organic Industry. Available online: https://www.qai-inc.com/ news-events/2018-us-farm-bill-win-organic-industry.php (accessed on 20 December 2019).

13. Greene, C. Emerging Issues in the US Organic Industry; USDA-ERS: Washington, DC, USA, 2009.

14. Klonsky, K.; Tourte, L. Organic agricultural production in the united states: Debates and directions. Am. J. Agric. Econ. 1998, 80, 1119-1124. [CrossRef]

15. Noel, B.; Biing-Hwan, L.; John, C.; Nicole, B. America's changing appetite: Food consumption and spending to 2020. Food Rev. 2002, 25, 2-9.

16. Dimitri, C.; Oberholtzer, L.; Marketing, U.S. Organic Foods: Recent Trends from Farms to Consumers. 2009. Available online: https:/ / www.ers.usda.gov/publications/pub-details/?pubid=44432 (accessed on 12 December 2019).

17. Taus, A.; Ogneva-Himmelberger, Y.; Rogan, J. Conversion to organic farming in the continental United States: A geographically weighted regression analysis. Prof. Geogr. 2013, 65, 87-102. [CrossRef]

18. Kuo, H.J. Socioeconomic Geography of Organic Agriculture in the United States, 2007-2012. Ph.D. Thesis, Iowa State University, Ames, IA, USA, 2015.

19. Anderson, J.B.; Jolly, D.A.; Green, R.D. Determinants of farmer adoption of organic production methods in the fresh-market produce sector in California: A logistic regression analysis. In Proceedings of the 2005 Annual Meeting, California Western Agricultural Economics Association, San Francisco, CA, USA, 6-8 July 2005.

20. Mala, Z.; Malý, M. The determinants of adopting organic farming practices: A case study in the Czech Republic. Agric. Econ. 2013, 59, 19-28. [CrossRef]

21. Rezvanfar, A.; Eraktan, G.; Olhan, E. Determine of factors associated with the adoption of organic agriculture among small farmers in Iran. Afr. J. Agric. Res. 2011, 6, 2950-2956.

22. Kostandini, G.; Mykerezi, E.; Tanellari, E. Viability of organic production in rural counties: County and state-level evidence from the United States. J. Agric. Appl. Econ. 2011, 43, 443-451. [CrossRef]

23. Walaga, C.; Hauser, M.; Delve, R.J.; Nagawa, F. Promoting organic agriculture in Uganda. ChemPhysChem 2005, 17, $931-953$.

24. Schafer, M.; Nolting, B.; Engel, A. Organic agriculture as a new player in sustainable regional development? Case studies of rural areas in eastern Germany. Int. J. Agric. Resour. Gov. Ecol. 2009, 8, 158-179. [CrossRef]

25. Stephenson, G.; Gwin, L.; Powell, M.; Garrett, A. Enhancing Organic Agriculture in Oregon Research, Education, and Policy; Oregon State University: Corvallis, OR, USA, 2012.

26. Berihun, K. Assessment of Factors Affecting Agricultural Production: Evidence from Smallholder Farmers of Southern Tigray, Northern Ethiopia. 2014. Available online: https://opendocs.ids.ac.uk/opendocs/handle/20.500.12413/4514 (accessed on 12 December 2019).

27. Ali, M.; Peerlings, J. Farm households and nonfarm activities in Ethiopia: Does clustering influence entry and exit? Agric. Econ. 2012, 43, 253-266. [CrossRef]

28. Batte, M.T.; Hooker, N.H.; Haab, T.C.; Beaverson, J. Putting their money where their mouths are: Consumer willingness to pay for multi-ingredient, processed organic food products. Food Policy 2007, 32, 145-159. [CrossRef]

29. Kiesel, K.; Villas-Boas, S.B. Got organic milk? Consumer valuations of milk labels after the implementation of the USDA organic seal. J. Agric. Food Ind. Organ. 2007, 5. [CrossRef]

30. Molyneaux, M. The changing face of organic consumers. Food Technol. 2007, 61, 22-26.

31. Peng, M. The Growing Market of Organic Foods: Impact on the US and Global Economy. In Safety and Practice for Organic Food; Academic Press: Cambridge, MA, USA, 2019; pp. 3-22. [CrossRef]

32. Qiao, Y.; Halberg, N.; Vaheesan, S.; Scott, S. Assessing the social and economic benefits of organic and fair trade tea production for small-scale farmers in Asia: A comparative case study of China and Sri Lanka. Renew. Agric. Food Syst. 2016, 31, 246-257. [CrossRef]

33. Davies, A.; Titterington, A.J.; Cochrane, C. Who buys organic food? Br. Food J. 1995, 97, 17-23. [CrossRef]

34. Shafie, F.A.; Rennie, D. Consumer perceptions towards organic food. Procedia-Soc. Behav. Sci. 2012, 49, 360-367. [CrossRef]

35. Morawetz, U.B.; Wongprawmas, R.; Haas, R. Potential income gains for rural households in North Eastern Thailand through trade with organic products. In Proceedings of the 105th Seminar, Bologna, Italy, 8-10 March 2007.

36. Evans, H.E.; Ngau, P. Rural-urban relations, household income diversification and agricultural productivity. Dev. Chang. 2010, 22, 519-545. [CrossRef] 
37. Archer, D.W.; Dawson, J.; Kreuter, U.P.; Hendrickson, M.; Halloran, J.M. Social and political influences on agricultural systems. Renew. Agric. Food Syst. 2008, 23, 272-284. [CrossRef]

38. Kallas, Z.; Kallas, Z. Farmers' objectives as determinants of organic farming adoption: The case of catalonian vineyard production. Agric. Econ. 2010, 41, 409-423. [CrossRef]

39. Dimitri, C.; Oberholtzer, L. Expanding demand for organic foods brings changes in marketing. J. Amber Waves $2010,8,3$.

40. Lohr, L.; Gonzalez-Alvarez, Y.; Graf, A. Predicting Organic Market Development with Spatial Analysis of Existing Industry Information. In Proceedings of the 2001 Annual Meeting, Chicago, IL, USA, 5-8 August 2001.

41. Constance, D.H.; Jin, Y.C.; Lyke-Ho-Gland, H. Conventionalization, bifurcation, and quality of life: Certified and non-certified organic farmers in Texas. J. Rural. Soc. Sci. 2008, 23, 9.

42. Adebiyi, S.; Okunlola, J.O. Factors affecting adoption of cocoa farm rehabilitation techniques in Oyo state of Nigeria. World J. Agric. Sci. 2013, 9, 258-265.

43. Anyanwu, O.S. Determinants of aggregate agricultural productivity among food crop farmers in Rivers State, Nigeria. J. Vocat. Educ. Technol. 2009, 6, 117-125.

44. Asfaw, A. The role of education on the adoption of chemical fertiliser under different socioeconomic environments in Ethiopia. Agric. Econ. 2015, 30, 215-228. [CrossRef]

45. Townsenda, R.F.; Kirstena, J.; Vinkb, N. Farm size, productivity and returns to scale in agriculture revisited: A case study of wine producers in South Africa. Agric. Econ. 1998, 19, 175-180. [CrossRef]

46. Helfand, S.M. Farm size and the determinants of productive efficiency in the Brazilian center-west. Agric. Econ. 2003, 31, 241-249. [CrossRef]

47. Abugamea, G.H. A Dynamic Analysis for Agricultural Production Determinants in Palestine: 1980-2003. In Proceedings of the International Conference on Applied Economics (ICOAE), Kastoria, Greece, 15-17 May 2008.

48. Byerlee, D.; Diao, X.; Jackson, C. Agriculture, Rural Development, and Pro-poor Growth: Country Experiences in the Post-Reform Era; World Bank: Washington, DC, USA, 2005.

49. Yamamoto, Y.; Ochi, S.; Kobayashi, S.; Furuya, J.; Kabir, M.S. Quantification of land suitability assessment for rice in Bangladesh using multiple regression analysis and GIS. J. Jpn. Agric. Syst. Soc. 2013, 29, 1-9.

50. Zeru, M.A. Assessment of factors that affect the performance of agricultural production, in the case of Amhara region, Ethiopia. Agric. Sci. 2018, 9, 1058-1069. [CrossRef]

51. Shen, W.C.; Liu, W.Q.; School, B. Does Debt Maturity Structure Cause Earnings Management?-Research Based on the Evidence of OLS and Quantile Regression. J. Guangxi Cadres Coll. Econ. Manag. 2019, 31, 45-53.

52. Kim, M.J. Understanding the determinants on household electricity consumption in Korea: OLS regression and quantile regression. J. Electr. J. 2020, 33, 106802. [CrossRef]

53. Almasarwah, A. Stock Price Informativeness and Profit Warnings: Empirical Analysis. In Proceedings of the 19th International RAIS Conference, Princeton, NJ, USA, 18-19 October 2020.

54. Stolze, M.; Lampkin, N. Policy for organic farming: Rationale and concepts. Food Policy 2009, 34, 237-244. [CrossRef]

55. Wheeler, S. Review of organic farming policy in Australia: Time to wipe the slate clean? J. Sustain. Agric. 2011, 35, 885-913. [CrossRef]

56. Watson, C.A.; Walker, R.L.; Stockdale, E.A. Research in organic production systems-Past, present and future. J. Agric. Sci. 2008, 146, 1-19. [CrossRef]

57. Wheeler, S.A. The influence of market and agricultural policy signals on the level of organic farming. In Proceedings of the 2006 Annual Meeting, Gold Coast, Australia, 12-18 August 2006.

58. Halpin, D.; Daugbjerg, C.; Schvartzman, Y. Interest-group capacities and infant industry development: State-sponsored growth in organic farming. Int. Political Sci. Rev. 2011, 32, 147-166. [CrossRef]

59. Willer, H.; Zerger, U. Demand of research and development in organic farming in Europe. In Proceedings-First SREN Workshop "Research Methodologies in Organic Farming" at the Research Institute of Organic Agriculture (FiBL); Food and Agriculture Organisation (FAO): Rome, Italy, 1999; pp. 57-92.

60. Archana, K. Role of Indian government in the development of organic agriculture. IOSR J. Agric. Vet. Sci. 2013, 2, 32-39. [CrossRef]

61. Jansouz, P.; Pahlavani, M.; Bidabadi, F.S. Research and development spending and value added of agricultural sector of Iran. Int J. Agron. Plant Prod. 2013, 4, 2097-2101.

62. Hartman Group. Organic 2006: Consumer Attitudes E Behavior, Five Years Later E into the Future; Hartman Group: Bellevue, WA, USA, 2006.

63. Stevens-Garmon, J.; Huang, C.L.; Lin, B.H. Organic demand: A profile of consumers in the fresh produce market. Choices 2007, 22, 109-116.

64. Ladvenicová, J.; Miklovičová, S. The relationship between farm size and productivity in Slovakia. J. Visegr. J. Bioeconomy Sustain. Dev. 2015, 4, 46-50. [CrossRef]

65. Aubert, M.; Enjolras, G. French labour-force participation in organic farming. J. Hum. Syst. Manag. 2017, 36, 163-172. [CrossRef]

66. Lohr, L.; Park, T.A. Labor pains: Valuing seasonal versus year-round labor on organic farms. J. Agric. Resour. Econ. 2009, 34, 316-331. 
67. Schneeberger, W.; Darnhofer, I.; Eder, M. Barriers to the adoption of organic farming by cash-crop producers in Austria. Am. J. Altern. Agric. 2002, 17, 24-31. [CrossRef]

68. Aubert, M.; Enjolras, G. Do short food supply chains go hand in hand with environment-friendly practices? An analysis of French farms. J. Int. J. Agric. Resour. Gov. Ecol. 2016, 12, 189-213. [CrossRef]

69. Jingzhong, Y.E.; Huifang, W.; Wang, C. Peasant-managed agricultural growth in China: Mechanisms of labour-driven intensification. Int. J. Sociol. Agric. Food 2013, 21, 155-171.

70. Zegler, C.H.; Renz, M.J.; Brink, G.E.; Ruark, M.D. Assessing the importance of plant, soil, and management factors affecting potential milk production on organic pastures using regression tree analysis. Agric. Syst. 2020, 180, 102776. [CrossRef]

71. Benin, S.; Smale, M.; Gebremedhin, B.; Pender, J.; Ehui, S. The determinants of cereal crop diversity on farms in the Ethiopian highlands/доклад на 25 конференцииІААE, Reshaping Agriculture's Contribution to Society. In Proceedings of the International Convention Centre, Durban, South Africa, 16-23 August 2003.

72. Offermann, F.; Nieberg, H. Economic Performance of Organic Farms in Europe; University of Hoheheim, Department of Farm Economics: Stuttgart, Germany, 2000.

73. Dubowitz, T.; Heron, M.; Bird, C.E.; Lurie, N.; Finch, B.K.; Basurto-Dávila, R.; Escarce, J.J. Neighborhood socioeconomic status and fruit and vegetable intake among whites, blacks, and Mexican Americans in the United States. Am. J. Clin. Nutr. 2008, 87, 1883-1891. [CrossRef]

74. Hassan, H.; Hussein, Y.; El-Gebaly, M.R. An Economic Study of the Most Important Factors Affecting the Production of Some Farm Crops in North Sinai. Sciences 2015, 5, 60-67.

75. Jansen, H.G.P.; Midmore, D.J.; Binh, P.H.; Valasayya, S.; Tru, L.C. Profitability and sustainability of peri-urban vegetable production systems in Vietnam. Neth. J. Agric. Sci. 1996, 44, 125-143. [CrossRef]

76. Mpawenimana, J. Analysis of Socio-Economic Factors Affecting the Production of Bananas in Rwanda: A Case Study of Kanama District. 2005. Available online: http:/ / citeseerx.ist.psu.edu/viewdoc/download?doi=10.1.1.923.8382\&rep=rep1\&type=pdf (accessed on 12 December 2019).

77. Bampasidou, M.; Salassi, M.E. Trends in US Farm Labor and H-2A Hired Labor. Choices 2019, 34, 1-6. 